\title{
ANALISIS SISTEM PENGENDALIAN INTERNAL PIUTANG DAN KERU- GIAN PIUTANG TAK TERTAGIH PADA BADAN USAHA BANDAR UDARA HANG NADIM BATAM
}

\section{ANALYSIS OF RECEIVING INTERNAL CONTROL SYSTEM AND UNCERTAIN ACCOUNT ACCOUNT ON HANG NADIM BATAM AIRPORT BUSINESS AGENCY}

\author{
Nopiawati ${ }^{1}$, Ravika Permata Hati ${ }^{2}$ \\ ${ }^{1}$ (Akuntansi, Ekonomi, Universitas Riau Kepulauan, Indonesia) \\ ${ }^{2}$ (Akuntansi, Ekonomi, Universitas Riau Kepulauan, Indonesia) \\ ${ }^{2}$ ravika.permata@gmail.com
}

\begin{abstract}
Abstrak
Tujuan penelitian ini adalah untuk mengetahui apakah sistem pengendalian internal piutang dan kerugian piutang tak tertagih yang ada pada Badan Usaha Bandar Udara Hang Nadim Batam sudah berjalan dengan baik, karena penjualan secara kredit juga memiliki resiko tidak tertagihnya sebagian atau seluruh piutang yang diberikan kepada konsesioner. Jenis penelitian yang dilakukan adalah penelitian deskriptif yang menggunakan data primer seperti hasil wawancara dengan pihak perusahaan dan data sekunder seperti struktur organisasi serta dokumen-dokumen yang berkaitan dengan sistem pengendalian internal piutang. Hasil penelitian menunjukkan bahwa sistem pengendalian internal piutang sudah berjalan dengan baik, walaupun masih adanya piutang tak tertagih yang disebabkan oleh beberapa hal. Untuk melakukan penghapusan piutang dalam hal penentuan kerugian piutang tak tertagih berjalan sesuai prosedur yang ada.
\end{abstract}

Kata Kunci ; Piutang, sistem pengendalian internal, piutang tak tertagih

\begin{abstract}
The purpose of this study is to determine whether the Receivables Internal Control and Losses on Bad Debts that s existed at the Badan Usaha Bandar Udara Hang Nadim has been running well, because the sale on credit has the risk of uncollection of some or all of the receivales. The type of research conducted is Descriptive Method using primary data such as the results of interviews with the company, and secondary data data such as Organizational Structure and Documents related to the Receivable Internal Control System. The results show that the internal control system of accounts receivable has been running well, although there are still bad debts caused by several things. To perform the write-off of receivables in terms of determination of bad debts losses run according to existing procedures.
\end{abstract}

Keywords ; receivable, internal system control, bad debt

PENDAHULUAN

Latar Belakang
Pesatnya pertumbuhan perekonomian dunia menyebabkan adanya peningkatan perkembangan dunia usaha. Banyak perus- 
ahaan mengembangkan inovasinya dan meningkatkan kinerjanya agar tetap bertahan dan semakin berkembang. Pada umumnya perusahaan mempunyai tujuan yang sama yaitu meningkatkan laba, untuk mencapai tujuan perusahaan tercapai maka perusahaan harus dapat bersaing secara kompetitif. Perusahaan harus mempunyai keunggulan dalam melakukan persaingan agar dapat beroperasi lebih efektif dan efisien sehingga perusahaan dapat menjaga kelangsungan usahanya dimasa mendatang.

Sistem pengendalian internal piutang yang benar merupakan sesuatu yang harus dilakukan oleh perusahaan. Apabila perusahaan memiliki sistem pengendalian internal piutang yang baik maka akan mempengaruhi juga keberhasilan perusahaan dalam menjalankan penjualan secara kredit. Begitu pula sebaliknya, jika dalam system pengendalian internal piutang terdapat kelalaian maka bisa berakibat fatal bagi perusahaan, misalkan menumpuknya piutang yang tak tertagih.

Timbulnya piutang usaha ini memiliki resiko dalam pelunasannya, diantaranya adalah piutang usaha tertagih dan piutang usaha tidak tertagih. Piutang usaha tak tertagih merupakan salah satu resiko yang harus ditanggung oleh perusahaan, sehingga tujuan awal perusahaan untuk memperoleh pendapatan sebesar-besarnya akan berbalik menjadi kerugian apabila tidak ada pengawasan yang ketat atas penjualan yang berhubungan dengan kredit. Oleh karena itu perusahaan yang melakukan penjualan secara kredit memerlukan suatu sistem pengendalian internal yang handal untuk mencegah adanya kerugian piutang yang tak tertagih, hal ini juga mencegah adanya fraud yang kemungkinan terjadi dalam pelunasan piutang. Berdasarkan uraian yang telah dijelaskan sebelumnya , maka penulis akhirnya memilih judul "Ana-

\section{lisis Sistem Pengendalian Internal Piutang dan Kerugian Piutang Tak Ter- tagih pada Badan Usaha Bandar Udara Hang Nadim Batam".}

\section{Tujuan Penelitian}

Tujuan dari penelitian ini adalah untuk mengetahui bagaimana sistem pengendalian internal piutang dan kerugian piutang tak tertagih pada Badan Usaha Bandar Udara Hang Nadim Batam .

\section{TINJAUAN PUSTAKA \\ Pengendalian Internal}

Pengendalian internal adalah proses yang dirancang untuk memberikan jaminan tercapainya tujuan yang berkaitan dengan efektivitas dan efisiensi operasi, reabilitas pelaporan keuangan, dan ketaatan pada peraturan hukum yang berlaku. Pemahaman yang baik terhadap pengendalian internal sangat diperlakukan baik oleh manajer, user sistem akuntansi, perancang sistem akuntansi, maupun evaluator sistem akuntansi (TMBooks, 2015:36).

\section{Sistem Pengendalian Internal atas Piutang}

Pada prinsipnya sistem pengendalian harus meminimalkan dan mendeteksi serta memperbaiki kesalahan ketika terjadi. Pelaksanaan sistem pengendalian intern untuk piutang harus menghasilkan suatu kepastian bahwa semua transaksi piutang telah dibukukan dan dapat dipertanggung jawabkan. Pengendalian intern terhadap piutang dimulai dari penerimaan order penjualan terus ke persetujuan atas order, persetujuan pemberian kredit, pengiriman barang, pembuatan faktur, verifikasi faktur, pembukuan piutang, penagihan piutang, yang akhirnya akan mempengaruhi saldo kas atau bank. 
Dalam hal ini harus diperhatikan pula retur penjualan secara periodik harus dibuat perincian piutang menurut golongan usianya untuk menentukan tindakan apa yang perlu dilakukan dan menilai apakah bagian kredit dan bagian inkaso telah bekerja dengan efisien.

\section{Tujuan Sistem Pengendalian In- ternal atas Piutang}

Pemberian piutna dimaksudkan untuk meningkatkan volume penjualan bagi sebuah perusahaan. Diharapkan dengan meningkatnya volume pejualan, maka sebuah perusahaan dapat memperoleh keuntungan. Namun ada beberapa resiko atas keberadaan piutang itu sendiri yang dapat merugikan perusahaan. Oleh karena itu perlu adanya pengendalian terhadap piutang tersebut. Untuk mengendalikan piutang, sebuah perusahaan perlu menetapkan kebijakan kreditnya. Kebijakan ini kemudian berfungsi sebagai standar. Apabila kemudian dalam pelaksanaan penjualan kredit dan pengumpulan piutang tidak dilakukan sesuai dengan standar yang telah ditetapkan, maka perusahaan perlu melakukan perbaikan.

\section{Piutang}

Tujuan utama dalam penjualan secara kredit atau pemberian kredit yang dilakukan oleh suatu perusahaan adalah memberikan kelonggaran kepada konsumen untuk mengembalikan atau melunasi kredit tersebut sesuai dengan waktu yang telah ditentukan sehingga bagi perusahaan akan timbul suatu piutang. Piutang tersebut merupakan suatu klaim yang dimiliki oleh perusahaan untuk menuntut pembayaran dalam bentuk uang atau penyerahan aktiva kepada pihak debitur.
Menurut Warren, Reeve dan Fess " piutang meliputi semua klaim dalam bentuk uang terhadap pihak lainnya, termasuk individu, perusahaan, atau organisasi lainnya". Selanjutnya pengertian menurut Dedhy dan Yi eke " piutang adalah tagihan kepada pihak lain untuk membayarkan uang dalam jumlah tertentu".

\section{Penilaian Piutang}

Piutang dilaporkan sebagai nilai realisasi bersih (net realizable value) yaitu nilai kas yang diharapkan akan diterima seperti yang diungkapkan oleh Zaki Baridwan (2008:125), penilaian utang sebagai berikut :"Piutang termasuk dalam komponen aktiva lancar. Dalam hubunganya dalam penyajian piutang didalam neraca digunakan dasar pengakuan nilai realisasi atau penyelesaian. Dasar pengukuran ini mengatur bahwa piutang dinyatakan sesuai bruto tagihan dikurangi taksiran jumlah yang tidak dapat diterima. "Sedangkan menurut James D. Stice (2009:247) yang diterjemahkan oleh Syam Setya penilaian piutang sebagai berikut :"Semua piutang dinilai dalam jumlah yang mewakili nilai sekarang dari perkiraan penerimaan kas dimasa yang akan datang".

\section{Metode Piutang Tak Tertagih}

Terdapat dua metode akuntansi untuk mencatat piutang yang diperkirakan tidak akan tertagih yaitu :

\section{Metode Penghapusan Langsung (di- rect write method)}

Metode penghapusan langsung merupakan metode yang digunakan untuk mencatat kerugian akibat adanya 
piutang tak tertagih. Dalam metode ini, perusahaan tidak melakuakn pencatatan ataupun selama suatu piutang belum ditentukan sebagai piutang tak tertagih dan akan dihapuskan. Metode ini akan mengabaikan kemungkinan akan adanya kerugian piutang tak tertagih sampai suatu piutang terbukti tak tertagih. Tidak ada penyisihan dimuka yang dibuat untuk piutang tak tertagih. Dalam hal ini piutang tak tertagih merupakan jumlah piutang yang benar-benar tak tertagih dalam suatu periode akuntansi. Setelah suatu piutang ditentukan untuk dihapuskan perusahaan membuat jurnal sebagaiberikut : Metode ini mengasumsikan bahwa dari setiap penjualan yang dihasilkan piutang usaha dengan baik, dan bahwa kejadian selanjutnya membuktikan bahwa piutang tertentu tidak dapat ditagih dan tidak bernilai. Metode penghapusan langsung ini pada umunya digunakan oleh perusahaan kecil, yang penjualanya lebih banyak secara tunai dari pada kredit atau pencatatan tentang penjualan kreditnya lebih singkat.

\section{Metode Penyisihan (allowance meth- od)}

Metode ini menggunakan penyisihan atau cadangan (allowance) dalam mencatat kerugian yang timbul akibat adanya piutang tak tertagih. Dalam hal ini pihak manajemen tidak menunggu sampai suatu piutang benar-benar tidak dapat ditagih, melainkan membuat suatu perkiraan jumlah kemungkinan piutang yang tidak dapat ditagih. Jumlah piutang yang tidak akan tertagih tersebut dapat diramalkan dari pengalaman masa lalu.

\section{Penelitian Terdahulu}

Hamel (2013) dengan judul Evaluasi Sistem Pengendalian Intern Terhadap Piutang Pada PT. Nusa Surya Sakti. Hasil penelitian menunjukkan bahwa sistem pengendalian intern yang ada di PT. Nusa Surya Sakti sudah efektif, kecuali pada unsur lingkungan pengendalian yang kurang efektif diakibatkan kurangnya pemeriksaan yang dilakukan audit internal untuk mengatasi praktek pelaporan keuangan dan membantu struktur keuangan dalam menyelesaikan fungsi pertanggung jawaban, sehingga dapat membuka peluang terjadinya kecurangan.

Taroreh (2016) dengan judul Evaluasi Penerapan Sistem Pengendalian Internal Piutang Usaha pada PT. Mandiri Tunas Finance Cabang Manado. Hasil Penelitian Menunjukan bahwa system pengendalian internal terhadap piutang usaha pada PT. Mandiri Tunas Finance Cabang Manado sudah berjalan cukup baik. Manajemen perusahaan telah menerapkan konsep dasar dan prinsip-prinsip pengendalian internal menurut kerangka COSO (Committee Of Sponsoring Oragnization) namun masih perlu beberapa perbaikan.

\section{METODOLOGI PENELITIAN Tempat dan Waktu Penelitian}

a) Tempat Penelitian

Badan Usaha Bandar Udara Hang Nadim Batam yang berlokasi di Jalan Hang Nadim No.1 Kelurahan Batu Besar-Batam.

b) Waktu Penelitian

Oktober 2017 - Februari 2017.

\section{Jenis Data}

Jenis data dalam penelitian ini terbagi dalam dua kategori yaitu sebagai berikut: 
1. Data Primer, yaitu data yang didapat secara langsung dari narasumber baik dalam bentuk observasi ataupun wawancara dengan didukung oleh dokumentasi.

2. Data Sekunder, yaitu data yang didapat melalui media perantara seperti Internet, Buku, Website dan referensi lainnya yang dapat mendukung penelitian.

\section{Teknik Pengumpulan Data}

1. Penelitian kepustakaan (library research), yaitu penelitian yang menggunakan data yang diperoleh dari tulisan-tulisan ilmiah yang ada maupun buku-buku literatur lain yang diperlukan sebagai landasan teoritis dalam penelitin ini.

2. Penelitian lapangan (field research), yaitu penelitian yang dilakukan untuk mendapatkan data-data dan informasi yang intern pada perusahaan yang bersngkutan. Data yang diambil sebagian besar diperoleh dengan teknik pengumpulan sebagai berikut:

\section{Definisi Operasional}

1. Pengendalian Internal Piutang Yaitu suatu proses atau metode bisnis yang dijalankan oleh manajemen untuk menjaga aset yang dimiliki dalamhal ini adalah piutang yang timbul akibat dari kegiatan operasional utama perusahaan.

2. Piutang Tak Tertagih

Yaitu suatu kerugian yang menjadi resiko perusahaan atas pemberian kredit karena adanya ketidakmampuan konsumen mengembalikan piutang yang menjadi hak perusahaan

\section{HASILPENELITIAN DAN PEM- BAHASAN}

Gambaran Umum Profil Perusahaan
Bandara Hang Nadim terletak di kelurahan Batu Besar, kecamatan Nongsa. Bandara ini mendapatkan nama dari Laksamana Hang Nadim yang termahsyur dari Kesultanan Malaka dan memiliki landas pacu sepanjang 4.025 meter yang menjadikan bandara ini sebagai pemilik landas pacu terpanjang di Indonesia. Bandara Hang Nadim mulai beroperasi pada tanggal 1 Januari 1984 dan resmi dibuka secara umum oleh Bapak Presiden Republik Indonesia yang kedua yaitu Soeharto pada tanggal 3 Januari 1995 yang melayani penerbangan baik domestik maupun internasional. Badan Usaha Bandar Udara Hang Nadim Batam adalah salah satu unit yang dikelola oleh BP. Batam dalam mendukung tercapainya Visi dan Misi.

\section{Sistem Pengendalian Internal terkait piutang pada Badan Usaha Bandar Udara Hang Nadim Batam.}

Pengendalian internal yang telah diterapkan oleh Badan Usaha Bandar Udara Hang Nadim Batam untuk penjualan kredit yang terkait dalam kegiatan penjualan kredit dan pencatatan piutang antara lain :

1. Memisahkan Fungsi -fungsi antar bagian, seperti pemisahan fungsi bagian marketing dan piutang dilakukan oleh bagian berbeda dan orang yang berbeda pula. Pemisahan fungsi ini menghindari penyalahgunaan wewenang dalam penjualan dan meminimalisir terjadinya fraud. Pemisahan fungsi piutang dan akuntansi, pemisahan ini bertujuan untuk menghindari penyalahgunaan wewenang dalam menentukan nilai piutang konsesioner dan saldo jaminan serta dapat mengotorisasi fungsi masing-masing tanpa memikirkan dua fungsi sekaligus. Badan Usaha Bandar Udara Hang Nadim Batam 
telahmelakukanpemisahan beberapa fungsi terkait pengendalian internal piutang agar resiko piutang tak tertagih bias dikendalikan, dan untuk menghindari terjadinya kesalahan dalam setiap transaksi yang berkaitan dengan piutang.

2. Pegawai atau staf yang terkait dalam menangani akuntansi piutang, harus dipisahkan dari staf penerimaan hasil tagihan piutang karena untuk menghindari kesalahan dalam pencatatan atau penginputan penerimaan kas guna mengurangi piutang. Badan Usaha Bandar Udara Hang Nadim Batam telah melakukan pemisahan pegawai atau staf yang terkait dalam setiap transaksi piutang, agar tidak terjadi kesalahan dalam pencatatan serta bagian piutang hanya terfokus pada penagihan atau pun piutangnya saja.

Semua transaksi pemberian kredit, pemberian potongan dan penghapusan piutang mendapatkan persetujuan dari pejabat yang berwewenang. Setiap transaksi yang ada pada Badan Usaha Bandar Udara Hang Nadim Batam harus mendapat persetujuan dari pejabat ataupun atasan yang berwewenang. Staf yang melakukan atau menginput data piutang, maupun menginput data penerimaan ketika konsesioner telah melakukan pembayaran, selanjutnya staf meminta verifikasi kepada atasan langsung yang berwenang sebelum di konfirmasi final oleh bagian kasir. Setiap transaksi yang ada di input ke Sistem FBMS, dengan setiap akun dan password pengguna masing-masing, untuk menghindari terjadinya penyalahgunaan wewenang, dan untuk mengetahui secara cepat akun pengguna apabila terjadi kesalahan dalam pencatatan pada sistem.
4. Piutang harus dicatat dalam buku-buku tambahan piutang atau buku besar pembantu piutang. Badan Usaha Bandar Udara Hang Nadim Batam telah mencatat piutang ke dalam buku besar pembantu piutang yang sering disebut kartu piutang. Kartu piutang sering digunakan pegawai yang ingin melakukan atau mengecek tagihan piutang yang masih ada, dan melampirkan kartu piutang kedalam surat konfirmasi piutang dan surat peringatan agar konsesioner lebih yakin terhadap utangnya yang ada.

\section{Piutang Tak Tertagih}

Piutang usaha Badan Usaha Bandar Udara Hang Nadim Batam dapat dikatakan sangat besar karena sebagian besar penjualan dilakukan secara kredit. Akan tetapi dengan penjualan yang tinggi tidak menutup kemungkinan semua akan tertagih. Beberapa masalah yang sering terjadi dan mengakibatkan piutang bisa tak tertagih :

1. Saat piutang sudah jatuh tempo, masih banyak piutang yang pembayarannya tidak tepat waktu atau sudah jatuh tempo, padahal Badan Usaha Bandar Udara Hang Nadim Batam telah melakukan pengendalian piutang dengan membuat surat peringatan ataupun konfirmasi piutang.

2. Pelanggan tidak menanggapi usaha perusahaan untuk menagih, walaupun Badan Usaha Bandar Udara Hang Nadim Batam telah membuat peringatan dari satu sampai tiga, konsesioner tidak menanggapinya.

3. Konsesioner yang valid serta konsesioner usahanya tutup.

4. Kegagalan staf dalam mencari lokasi untuk melakukan penagihan juga bisa mengakibatkan piutang menjadi tak ter- 
tagih. Adanya perusahaan induk diluar daerah juga bisa membuat kesulitan dalam penagihan, apalagi jika perusahaannya pindah lokasi atau alamat tanpa melakukan konfirmasi terlebih dahulu, itu akan membuat Badan Usaha Bandar Udara Hang Nadim Batam mengalami kesulitan dalam mencari lokasi untuk melakukan penagihan.

\section{PEMBAHASAN}

Besarnya jumlah Piutang Tak Tertagih yang muncul di Badan Usaha Bandar Udara Hang Nadim Batam disebabkan oleh beberapa hal, antara lain :

1. Untuk Piutang lama (Piutang Usaha yang ditagihkan sebelum Sms II 2015) sudah dilakukan Penagihan sesuai dengan SOP dan dasar-dasar hukum yang berlaku di Unit tersebut (Penagihan, Pesuratan dan Pemanggilan) namun alamat debitur sudah tidak valid (sudah pindah).

2. Beberapa Debitur yang sudah sudah tidak beroperasi, tanpa adanya pemberitahuan untuk pengakhiran Perjanjian Kerjasama dengan Badan Usaha Bandar Udara Hang Nadim Batam sebelum masa berlaku kontrak habis.

3. Beberapa Debitur yang memiliki kondisi keuangan yang kurang baik, sehingga tidak memiliki kemampuan untuk melunasi piutang atau dalam tahap pelunasan bertahap.

4. Badan Usaha Bandar Udara Hang Nadim Batam telah menyerahkan Piutang Macet tersebut ke KPKNL sebagai langkah lanjutan dalam proses penagihan, dimana sampai saat ini masih dalam proses tindak lanjut oleh KPKNL, se- hingga masih dicatat sebagai Piutang Usaha kategori Macet.

5. Perubahan Penerapan Tarif yang masih belum final antara Badan Usaha Bandar Udara Hang Nadim Batam dan beberapa Debitur (Perbedaan tarif antara Perka BP. Batam dan PMK).

6. Temuan BPK RI terkait butir pengenaan denda di Kontrak Kerjasama terkait keterlambatan pelunasan faktur dan keterlambatan pelaporan hasil penjualan debitur sebagai dasar penagihan konsesi tahun 2012, yang ditagihakan melalui faktur di tahun 2013 sehingga dicatat sebagai Piutang Usaha Lainnya.

\section{KESIMPULAN DAN SARAN \\ Kesimpulan}

Bahwa Sistem Pengendalian Internal Piutang di Badan Usaha Bandar Udara Hang Nadim Batam telah dilaksanakan dengan baik. Sebelum debitur aktif beroperasi di Badan Usaha Bandar Udara Hang Nadim Batam, debitur harus menyetorkan Uang Jaminan yang bila pada akhir Masa Kontrak tidak memiliki tunggakan akan dikembalikan.

Adapun Piutang Tak Tertagih yang masih muncul di Badan Usaha Bandar Udara Hang Nadim Batam adalah karena beberapa debitur yang sudah tidak aktif (pailit) dan sudah ada putusan pengadilan, beberapa debitur yang mengalami kesulitan kondisi keuangan sehingga dalam proses pencicilan dan Temuan BPK RI tahun 2012 yang dicatat sebagai Piutang Usaha Lainnya sehingga di SMS II 2015 sudah menjadi kategori Piutang Macet / Piutang Tak Tertagih.

\section{Saran}


1. Dalam rangka melancarkan operasional perusahaan, Badan Usaha Bandar Udara Hang Nadim Batam hendaknya secara teratur mengadakan perputaran atau pertukaran jabatan atau sering disebut disebut mutasi jabatan. Hal ini dimaksud selain untuk keterampilan karyawan juga yang utama untuk pengendalian badan usaha.

2. Dalam melancarkan kegiatan piutang, alangkah baiknya pada bagian piutang, staf yang melakukan pekerjaan mengenai piutang dan piutang tak tertagih di tambah lagi, agar proses pengiriman surat konfirmasi dan peringatan dapat berjalan lebih tepat waktu.

3. Memisahkan fungsi penagihan dan fungsi kredit atau piutang, hal ini dapat membantudalam mengoptimalkanproses penagihan.Karenafungsi penagihan berfokus pada penagihan piutang secara langsung ke pelanggan. Bagian piutang atau kredit hanya berfokus pada pencatatan piutang dan pertanggung jawaban kepada kepala bagian piutang atas penagihan piutang.

\section{DAFTAR PUSTAKA}

Agustina, Ria. (2009). Analisis Efektivitas Manajemen Piutang ( Studi Kasus PT Unitex Tbk Bogor ), Fakultas Ekonomi dan Manajemen. Institut Pertanian Bogor.

A.P. Dera, J.J. Sondakh., J.D.L. Warongan. (2016) Analisis efektivitas sistem pengendalian internal piutang dan kerugian piutang tak tertagih pada PT. Surya Wenag Indah Manado, Jurnal EMBA Vol 4 No. 1 Maret 2016, Hal. 1498-1508.
E.Duchac, Reeve, Warren, (2015). Pengantar Akuntansi, Edisi 25, Penerbit Salemba Empat, Jakarta.

Hamel, Gary (2015), Evaluasi Sistem Pengendalian Intern Terhadap Piutang Pada PT. Nusantara Surya Sakti, Jurnal EMBA. Vol.1. No. 326 November 2015. Hal.274-281.

J.R. Taroreh, J.D.L Warongan, T. Runtu (2016). Evaluasi penerapan sistem pengendalian internal piutang pada PT Mandiri Tunas Finance Cabang Manado, Jurnal EMBA, Vol.4 No. 3 September 2016, Hal 125-134

Natalia Nur Afifah (2015), Analisis Sistem Pengendalian Internal atas Piutang pada PT GIS. E- jurnal Spirit Pro Patria Vol 1 Nomor 1 April 2015, E-ISSN 2443-1532.

R.D. Runtu, I. Elim (2016) .Analisis Pengendalian Intern Piutang Usaha pada PT. Bussan Auto Finance (BAF)Manado Jurnal EMBA.Vol 4 No. 1 Maret 2016, Hal. 536-545

Reeve J, Warren C, Duchac J. E, Wahyuni E, Suprianto G (2009), Principles Of Accounting2 - Indonesian AdaptionBuku 1, Penerbit Salemba Empat, Jakarta.

Riyanto, Bambang (2010). Dasar- Dasar Pembelanjaan Perusahaan, ed. 4, BPFEYOGYAKARTA

Warren, R.F.(2008). Pengantar Akuntansi, Edisi 21, Buku Satu. Salemba Empat. Jakarta. 